\title{
多雪域にある湿原の地下水変動について VARIATION IN GROUNDWATER LEVEL OF A MIRE IN A SNOWY REGION
}

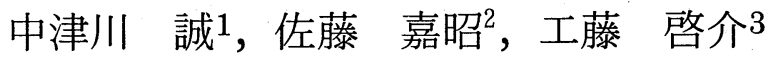 \\ Makoto NAKATSUGAWA, Yoshiaki SATO and Keisuke KUDO \\ 1正会員 博士（工学） 独立行政法人 北海道開発土木研究所（T062-8602 札幌市豊平区平岸1条3丁目1-34） \\ 2 正会員 独立行政法人 北海道開発土木研究所（テ062-8602 札幌市豊平区平岸1条3丁目1-34）

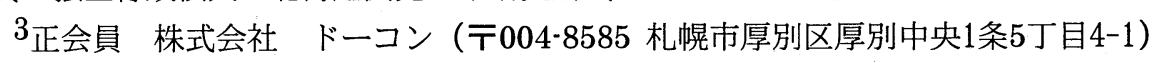

\begin{abstract}
In Sarobetsu Mire, the groundwater level has been dropping for the past few decades. There is great concern regarding the increase in sasa bamboo distribution and the displacement of the original vegetation. In the region of the mire, snow plays an important role in stabilizing the ground water level, especially in the bog area, because it recharges abundant amount of water to the groundwater.

Observation data showed that the ground water level in the bog area is kept high in winter by meltwater recharge from the bottom of the accumulated snow. An attempt was made to analyze the effect of snowmelt on groundwater level variation using a two-dimensional unsteady model. The simulation results indicated that lowering of groundwater level in the bog area could strongly relate to a decrease in snowmelt water. This means that mire conservation must take into account not only artificial influences like reclamation but also climate influences.
\end{abstract}

Key Words : bog, invasion of sasa bamboo, groundwater variation, snowmelt, snowy region

\section{1. はじめに}

「湿原」にはかつて暗く湿った不毛な土地, どちらか というと厄介者のイメージがあったが, 多様で貴重な動 植物の遺伝子源を確保する場, 洪水調節, 水資源確保や 水質浄化, 気候緩和, レクリエーションや環境教育の場 といった多角的機能が認識されるとともに, 保全の必要 性が訴えられている. ところで, 現状での湿原面積をみ ると, 平成12年 $(2000)$ 現在, 全国で $820.97 \mathrm{~km}^{2}$ であり, 北海道の湿原面積は $708.67 \mathrm{~km}^{2}$ となっていてその殆ど （86\%）が北海道に存在していることがわかる. 一方, 大正時代までさかのぼると, 湿原の面積は, 全国で $2,110.62 \mathrm{~km}^{2}$, 北海道で1,771.99 $\mathrm{km}^{2}$ となっており, 消滅し た湿原の広大さが数字の上でも理解できる（釧路湿原自 然再生協議会 ${ }^{1)}$ ) . なお, 本研究で対象としたサロベッ 湿原も元来の面積の半分以上が失われていると言われて いる $\left(\right.$ 冨士田 $\left.{ }^{2}\right)$ ）。湿原はきわめて微妙な立地環境のバ ランスの上に成立しているため, 人為的影響をとくに受 けやすく, これ以上の喪失を食い止めるためにも, 湿原 の形成メカニズムを理解することが不可欠となる.

ところで, 名前の通り, 湿っていてこそ湿原たる所以 であり, 言い換えれば地表面すれすれの高い地下水位が 湿原を特徵づけるものである. 湿原域の地下水について

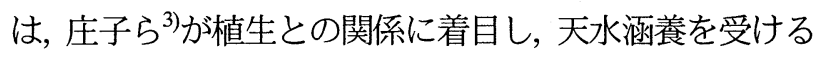
植物群落と, 河川水あるいは周囲の地下水からの涵養を
受ける植物群落の違いを報告している. また, 梅田らొは 湿原域に侵入して問題となっているササに注目し, ササ やミズゴケの生息域での地下水の動向を報告している. 以上から, 当該区域で保全の眼目と言える高層湿原 (Bog) では, 地下水位が高く, かつ変動が少ない状況で 維持されることが望ましいとされる.

本研究では, 北海道にあるサロベツ湿原を対象に, 湿 原域の地下水がどのような条件で維持され, 変動してい るかを既報 $\left(\right.$ 羽山ら $\left.{ }^{4)}\right)$ に引き続き明らかにすることを 目的とする. とくに, 地下水環境の理解を進めるため, 多雪域の湿原において雪の果たす役割に着目した.ここ では数力年にわたって実施された積雪調查に基づき, 湿原域では非湿原域より融雪が多いことを明らかにした. 一方, 高層湿原域にある地下水位は1月から3月にかけて の積雪期に高いことを見いだした. このことは積雪域の 湿原では融雪期だけでなく, 厳冬期における積雪底面か らの融雪が大きな涵養源となり, 高い地下水位を維持す る要因となっていることを示唆する. とくにサロベツ湿 原に広く分布する高層湿原（Bog）の環境は, 天水から の涵養に大きく依存しているため, 積雪の変動は大きな 影響を及ぼすとみられる.

以上を踏まえ, 様々な要因による湿原の水環境への影 響を分析することを目的に, モデルによる地下水動態の 把握を試みた. ここでは湿原内の地下水を不圧地下水と して扱い, 2次元非定常モデルに有限要素法を適用して計 


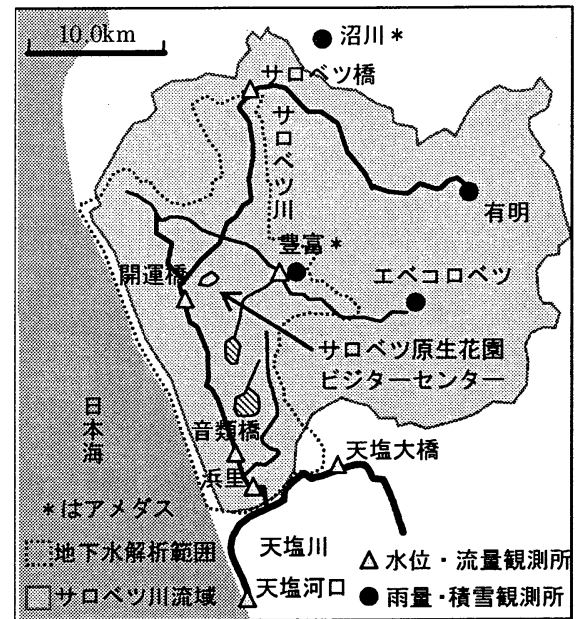

図-1 サロベッ川流域図

算を実施する.この際，1) 初期水位デー夕の設定，2）パ ラメー夕 (透水係数) の同定, 3) 雨水, 融雪, 蒸発散量 といった有効涵養量の設定, 4) 計算の実施, という手順 上の課題がある.11)については地形（標高）をトレンド 成分とし, Kriging法によって地下水位を推定する手法が 張らのによって提案されており, それを適用した.2) は張 $ら^{6}$ や羽山らかが検討した最適化手法に基づく結果を用い た. 3) は羽山らわによる河川流量の解析から有効涵養量 を推定する手法が提案されており，その結果を用いた.4) については, 様々な計算ルーチンやパッケージソフトが 開発されているが, ここではキンツェルバッパのの記し たガラーキン法を参考に計算を進めた.

一連の解析により, 地下水涵養源としての雪の役割を 明らかにした. また，それをモデル化することで, 地下 水への影響要因を分析し, 湿原保全策の検討に生かして いくことができると考える.

\section{2. サロベツ湿原の概要")とササ地の拡大について}

本研究で対象としたサロベツ湿原は, 図-1に示すよう に北海道北部日本海側の北緯 $45^{\circ} 05^{\prime}$, 東経 $141^{\circ} 10^{\prime}$ に位置し，南北におよそ $27 \mathrm{~km}$ ，東西におよそ $5 \mathrm{~km} \sim 8 \mathrm{~km}$ のほぼ長方形をなし，かつての面積は約 14,600ha $\left(146 \mathrm{~km}^{2}\right)$ であったが, 最近では3,000ha $\left(30 \mathrm{~km}^{2}\right)$ まで 減少しているとのことである2). 湿原のある原野内には サロベツ川が流れるほか, 周辺丘陵地を源とするいくつ かの川が合流して南下し，南西隅で天塩川に注いでいる. 原野は標高 $1 \sim 8 \mathrm{~m}$ の低地からなり, 中央部には約 $250 \mathrm{ha}$ $\left(2.5 \mathrm{~km}^{2}\right)$ の洪積台地, 丸山（標高8.5 13.4m）がある. また, 湿原の中央部には南北に並んでペンケ沼, パンケ 沼が, 北端には鼿沼がある.

サロベツ湿原を特徵づける植物群落はミズゴケ

(Sphagnum) などの高層湿原とヌマガヤ（Moliniopsis japonica）を優占種とする中間湿原であり, 夏季には花が 咲き乱れ彩りに富んでいる. 高層湿原とは, 周囲より標
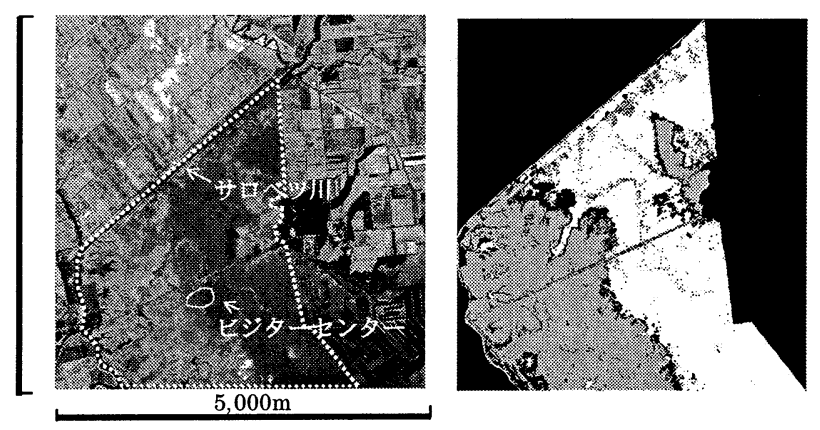

図-2 画像解析範囲（左図）と湿原植生の変化（右図） (左図; 点線内が画像解析範囲, 右図; 画像解析範囲内の 黒い部分が1977から2000’年の間にササ地に変化）

高が若干高く, 雨水や融雪水だけが水の供給源となる湿 原で, 貧栄養な環境で生息できるような植生環境となる. ここでは, 植生の生長と枯死を繰り返し, 土壌堆積のス

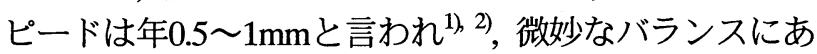
る環境が一度失われると回復が難しい。

サロベツ湿原では環境の変化にともなうササの拡大が 䀣念されており，その制御が課題となっている. ササ地 の拡大の原因としては, 過去の河川改修や排水溝の整備, 湿原の農地化が相対的に地下水位を低下させ, ササの侵 入を助長していると指摘されている2). ササ地の拡大状

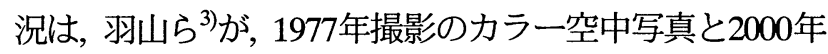
の高解像度人工衛星（IKONOS）画像から教師デー夕付 きの最尤法によってササ地を判別した結果を報告してい る. 図-2にはその間23年間での湿原植生の変化状況を 示す. 右図の白い部分は高層湿原域で西側（図の左方 向）にいくに従い，図中灰色で示すササの繁茂が目立つ ようになる. ササ地はサロベツ川と平行に南北方向に広 がり, 徐々に東側に拡大していることを示している.

\section{3. 積雪条件と地下水について}

北海道開発局留萌開発建設部では湿原内で地下水位の 連続観測を実施している.この中で開運橋観測所から東 へ向かって設置されている観測井（位置図は図-3）の データを図-4に示す. サロベツ放水路と道路に挟まれた 区域でサロベツ川に近い順にH8B3，H8B2，H8B1の1ケ年 （2000年）の日平均地下水位である.これをみると，河 川から離れているH8B1では夏季の水位変化はほとんど みられないが, H8B2, H8B3では地下水位は細かい変動を しており，とくに4月はサロベッ川（開運橋）の水位と 同様に水位上昇か湿著である. なお, H8B1, H8B2周辺に は高層湿原が広がっている. また, 図-5にはH8B1の1997 ２000の月平均地下水位と積雪深を示すが，積雪状況に 応じて1月から4月頃の地下水位が概して高く, 地下水涵 養が積雪と融雪に深く関係していることを示唆している. これは積雪底面の融雪が地下水涵養源であり，雪の断熱 性によりそれを助長させている可能性が考えられる.い 


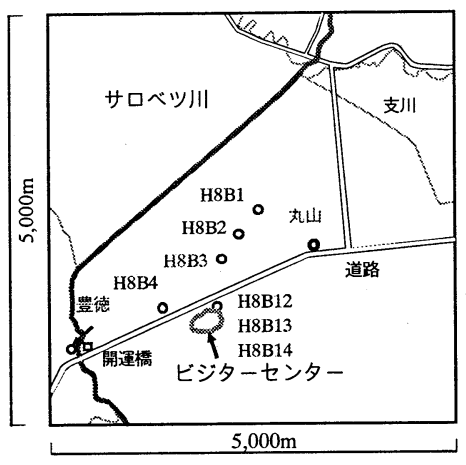

図-3 ビジターセンター付近の概要図 （白抜き丸が地下水観測井）

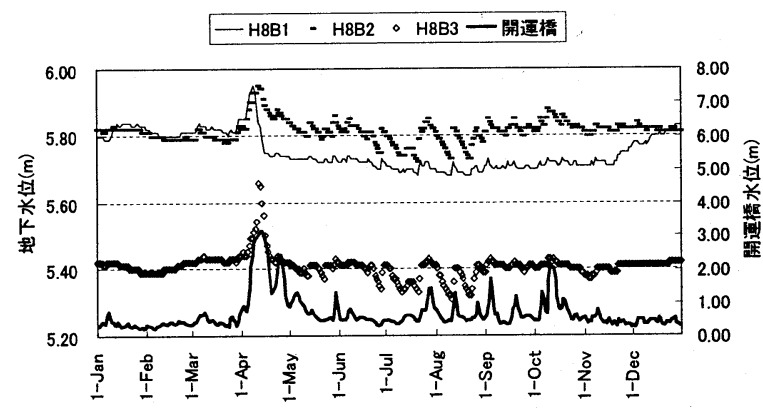

図-4 ビジターセンタ一付近の河川水位と地下水位の変動 (2000年の日平均値)

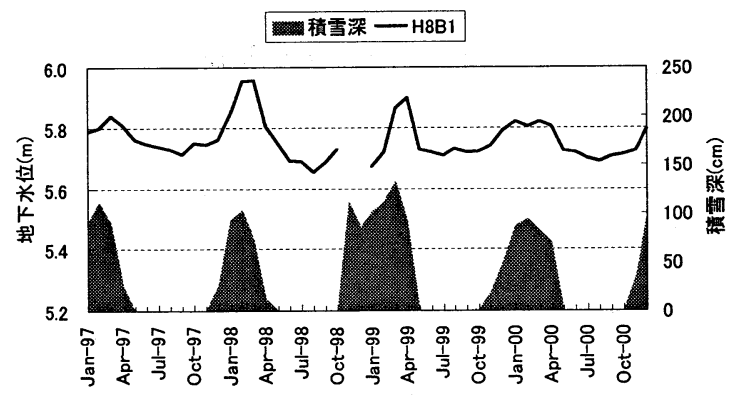

図-5 ビジターセンタ一付近の地下水位と積雪深 （1996年-2000年の月平均值）

ずれにしても，積雪量および融雪期の水文条件がサロべ ツ湿原の地下水に大きな影響を与えているのは間違いな いであろう. また, 植物生長の最も旺盛な時期である6〜 8月が地下水位の低い時期であることもササの侵入を考 えるうえで注目できる.

以上を踏まえ，次に湿原内と市街地における積雪の違 いをみてみたい.ここで用いるデータは2002年1月より 2004年3月まで計18回にわたり実施したスノーサーベイ から得られたものである.

図-6には市街地にある「豊富（トヨトミ）」地点と， 湿原内にある「ビジターセンター」および「開光橋」の 積雪水量 $(\mathrm{mm})$ を示す. 豊富とほか2地点は距離にして $7 \mathrm{~km}$ ほどで, 標高は豊富が12m，ほか2地点が3m程度であ り 降雪量は同程度と考えられる. しかしながら, 豊富に 比べ湿原内では積雪水量が常に少ない。積雪調查は「豊 富」では小学校のグランドなど, いずれも構造物等の影 響を受けない平地の雪原で行ったが，このような違いが

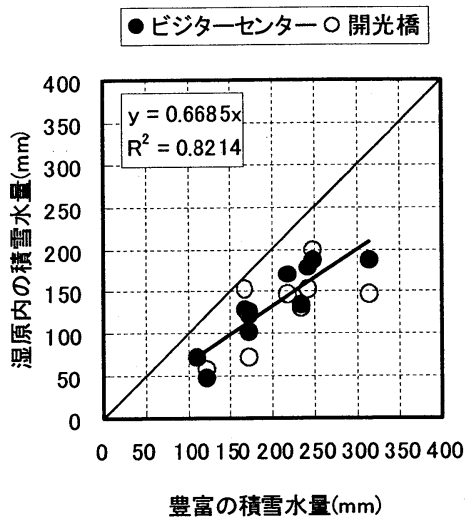

図-6 豊富と湿原内の積雪水量の比較 (2002年-2004年のスノーサーベイより)

生じるのは底面融雪により厳冬期も地中への水供給が起 きていることによると考えられる. 積雪水量の比率から みると, 他の2地点は豊富の約7割という結果が得られた. これから湿原で余分に発生する底面融雪速度 $m_{b}$ を, 下式 によって推定する.

$$
m_{b}=\frac{\left(1-\alpha_{0 i}\right) \Delta S_{0}}{\Delta t}
$$

ここで, $\alpha_{0 i}$ は豊富地点に対する湿原内の積雪水量比 $(=0.7), \Delta S_{0}$ は前回積雪調査 $(t=t-\Delta t)$ 㘦今回 積雪調查 $(t=t)$ までの豊富地点の積雪水量の変化 $(\mathrm{mm}), \Delta t$ は経過日数（days）である. 実際に厳冬期 である1月および2月に実施された積雪調查の結果から上 記 $m_{b}$ の平均值を求めると $0.95 \mathrm{~mm} / \mathrm{d}$ となった. すなわち, 湿原内では他より $1 \mathrm{~mm} / \mathrm{d}$ の底面融雪が余分にあることを 意味し，ここで起きる連続的な涵養が湿原内の地下水位 を高く保持する要因と考えられる.

\section{4. 有限要素法による地下水計算手法}

\section{（1）モデルとガラーキン法による計算手法}

地下水シミュレーションは, 湿原内の地下水を不圧地 下水として扱い，次式に示す2次元非定常モデルを適用 しておこなう.

$$
\frac{\partial}{\partial x}\left(T \frac{\partial h}{\partial x}\right)+\frac{\partial}{\partial y}\left(T \frac{\partial h}{\partial y}\right)+q_{0}=S \frac{\partial h}{\partial t}
$$

ここで, $h$ は地下水位 $(\mathrm{m}), T$ は帯水層の透水量係数 $\left(\mathrm{m}^{2} / \mathrm{s}\right)$ で 透水係数 $k(\mathrm{~m} / \mathrm{s})$ に帯水層厚さ $(\mathrm{m})$ を乗じたもの, $S$ は貯留係 数, $q_{0}$ は涵養量または揚水量 $(\mathrm{m} / \mathrm{s})$ である.

上式を有限要素法（FEM）によって数值的に解くため, ガラーキン法を適用する. ここで, 計算ルーチンはキン ツェルバッハ ${ }^{8}$ が記したものを参考とした. FEMでは解析 対象空間を多角形要素（本例では三角形）に離散化し， 要素内の変数を空間座標に応じて重みづけ内挿するよう な関数 $\phi$ 考える.この関数との線形結合により次のよ うに近似解 $\hat{h}$ 与える. 


$$
\hat{h}=\sum_{i=1}^{N} h_{i} \omega_{i} \text { ここで } \quad \omega_{i}=\sum_{e=1}^{M} \phi_{i}^{e}
$$

ここで, は節点を表す添え字, $N$ は節点数, $e$ は要素を表す 添え字, $M$ は要素数, $\omega_{i}$ は基底関数と称する. これを式 (1)に代入すると, 次式を得る.

$$
\varepsilon=\frac{\partial}{\partial x}\left(T \frac{\partial \hat{h}}{\partial x}\right)+\frac{\partial}{\partial y}\left(T \frac{\partial \hat{h}}{\partial y}\right)+q_{0}-S \frac{\partial \hat{h}}{\partial t}
$$

ガラーキン法では上記 $\varepsilon$ を最小にする方法として, 次 式が要求される.

$$
\int_{\Omega} \varepsilon \omega_{i} d x d y=0
$$

ここで, 上式は $x, y$ 平面上の境界 $\Gamma$ をもつ領域 $\Omega$ での残 差 $\varepsilon$ と基底関数 $\omega$ の積を積分したものを 0 とした場合, $h$ の最適解が得られるというものである. この積分の結果, 次式を得る.

$$
\sum_{j=1}^{N} P_{i j} h_{j}+\sum_{j=1}^{N} R_{i j} \frac{\partial h_{j}}{\partial t}-F_{j}=0
$$

ここで,hにかかる係数行列は次のように表せる.

$$
\begin{aligned}
P_{i j} & =\sum_{e=1}^{M} \int_{e}\left(T^{e} \frac{\partial \phi_{i}^{e}}{\partial x} \frac{\partial \phi_{j}^{e}}{\partial x}+T^{e} \frac{\partial \phi_{i}^{e}}{\partial y} \frac{\partial \phi_{j}^{e}}{\partial y}\right) d x d y \\
R_{i j} & =\sum_{e=1}^{M} \int_{e} S^{e} \phi_{i}^{e} \phi_{j}^{e} d x d y \\
F_{i}^{e} & =\sum_{e=1}^{M}\left(\int_{e} q \phi_{i}^{e} d x d y+\int_{\Gamma} \phi_{i}^{e} q_{n} d s\right)
\end{aligned}
$$

ここで, 3番目の式の右辺第2項は境界に沿った線積分を

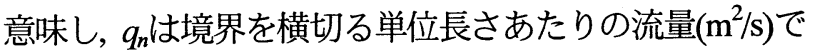
ある. これらの積分は, Pinder et. al. ${ }^{10)}$ ，あるいはフヤコー ンら ${ }^{11}$ の著作を参考に, 要素サイズに応じて定式化され た式から求める. 結局, 式(6)は時間に関する連立常微分 方程式となり，これを次のような陰解法によって解く.

$$
\left(\frac{[R]}{\Delta t}+[P]\right) h(t+\Delta t)=\left(\frac{[R]}{\Delta t}\right) h(t)+[F]
$$

ここで, $[P],[R],[F]$ は式(7)の係数行列である. なお, サロ ベツ湿原を対象とした計算は, 1 辺 $500 \mathrm{~m}$ の三角形要素を ユニットに, 要素数が1,903個, 節点が1,051個である. ま た, 計算の時間ステップは1day（86,400sec）とした.

\section{（2）計算条件の設定}

諸条件の設定は，すでにサロベツ湿原を対象とした地 下水シミュレーションをおこなってきた張らの, 羽山ら の手法を参考にした.

「透水量係数」Tは, 2 次元定常地下水流動モデルに Gauss-Newton法を適用し, 節点ごとに同定したものに基 づく. 透水係数はこれを帯水層厚さで除して得られ, $10^{-4}$ $\sim 10^{2} \mathrm{~m} / \mathrm{d}$ のオーダーにある. また，「貯留係数」Sは0.25
とする. なお, 最終的には透水量係数は, 実際の地下水 位の再現状況をみながら調整された值としている.

「初期水位」は, ROKMT法 (Residual Ordinary Kriging with Modified Trend) を用いて1997年10月の一斉地下水調 查の結果から推定したものに基づく. 今回の計算では 1999年と2000年の地下水位を計算するが, 前段で1998年 の地下水位の計算をおこなっている.

「揚水量」は, 地下水利用がほとんどないものと考え てゼロとする. 一方, 大気・地表面間の熱収支を定式化 した2層モデル (口澤ら $\left.{ }^{12}\right)$ ) で融雪量や蒸発散量が推算 できるが，これから1年を通した正味の地表面水供給量 が得られ，涵養率を乗じて「有効涵養量」を求めること ができる.ここで地下水への涵養率は河川流量の成分分 離と流域水収支の整理に基づき0.16としている.これら から式(2)の $q_{0}$ を与える. なお, $q_{0}$ の年間総量は, 上記推算 より求めた「降雨 $(900 \mathrm{~mm} / \mathrm{yr})+$ 融雪 $(500 \mathrm{~mm} / \mathrm{yr})$ - 蒸発散 $(700 \mathrm{~mm} / \mathrm{yr})\lrcorner$ の值に0.16を乗じた $110 \mathrm{~mm} / \mathrm{yr}$ 程度となる.

「境界条件」は解析対象範囲の主要河川・湖沼の実測 水位を内挿し, 定水頭境界として与える. また, 解析対 象範囲外からの流入については, 水収支解析に基づき流 量依存の水頭境界として与える. また海域境界は定水頭 境界として0mを与える.

\section{5. モデルによる地下水変動要因の解析}

\section{（1）湿原域の地下水位の再現}

上記モデルを用い，図-1の湿原全体の解析範囲につい て計算をおこない, ビジターセンタ一付近の約 $5 \mathrm{~km}$ 四方 の範囲（図-2の範囲に相当）について再現結果を示した ものが図-7である. なお，ここでの実測コンターとは ROKMT法による空間内扦をおこなったものである. 図 には.2000年4月の地下水分布を表わすが, ビジターセン タ一付近はちょうど地下水頭の尾根部にあたり, 地下水 位の高い領域となっていることがわかる. また, 図-8は 地下水位の最も高い4月と低い7月の計算水位の偏差をあ らわしたものだが, ビジターセンタ一付近は地下水位の 変動が少ないことがわかる. なお, 計算領域内で設定さ

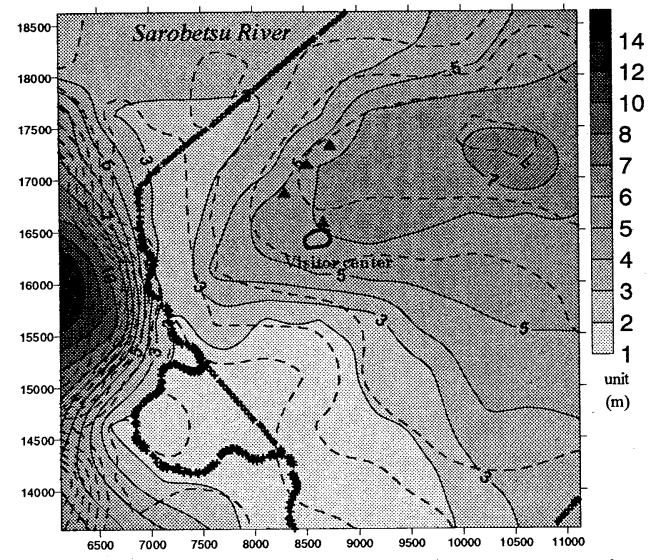

図-7 地下水位の再現結果（2000年4月の結果） （点線; ROKMT法による実測補間, 実線色付; 計算) 
れた「透水係数」は $10^{4}$ から $10^{2}(\mathrm{~m} / \mathrm{d})$ のオーダーにあ るが, この付近はその中でも小さい值をとる領域で, 地 盤高加の相対的な地下水位も高い. すなわち, 雨水や 融雪水からの涵養を受けて地下水位は高く, 安定しやす い構造となっていることがわかる. 高層湿原はまさにそ のような場所に形成されるので, 本モデルが湿原に特徵 的な地下水構造を表していると考える.

\section{（2）雪に関わる要因の感度分析}

冬期間の底面融雪が地下水に及ぼす影響をシミュレー ションによって分析してみる. 実際には既往の検討（羽 山ら $\left.{ }^{7)}\right)$ で用いていた底面融雪量 $1 \mathrm{~mm} / \mathrm{d}$ の場合と, 前々

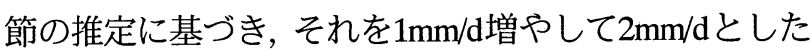
場合に, 地下水位にどのような差が現れるかを計算した. 各月の融雪量を2層モデルで与えて地下水位を計算し， 差分を図示したのが図-9である. 図では2000年2月につ いて $2 \mathrm{~mm} / \mathrm{d}$ の結果から $1 \mathrm{~mm} / \mathrm{d}$ の結果を差し引いた值を示 している.この結果, $1 \mathrm{~mm} / \mathrm{d}$ の底面融雪量の増加は地下水 位にして $5 \mathrm{~cm}$ 程度の上昇に相当すると推算された. これ は図-4に示したH8B1の冬期地下水位が他の時期より数 cmほど高いことからもほぼ妥当な感度と考えられる. 高 層湿原では, 夏期に降雨があっても地下水位はほとんど 変動しないと言われている. しかし, 冬期間に底面融雪 からの継続的供給があると, 変動が少ないことに変わり はないものの, 他の期間より地下水位が高く保持されて いる. このことから, 夏期降雨のような断続的な供給よ りも, 積雪期間の底面融雪のような継続的な供給の方が 地下水位の増減を左右するものとみることができる.

次に, 雪そのものの変化が地下水位にどのような影響 を及ぼすかをみてみる. 計算では1999年と2000年の2力 年において4月の融雪量を現状より $100 \mathrm{~mm}$ 減らした場合 の地下水位の変化をみた. 図-10は, 2000年4月において 現状と融雪量を減らしたケースについて地下水位の差を 表したものである. 低下量自体は $100 \mathrm{~mm}$ 減という仮想的 な条件下の結果なので, その值に厳密な意味はない.こ こで注目していただきたいのは, 地下水低下が顕著に起 きている区域の分布である. 地下水頭の尾根部にあたる ビジターセンタ一付近は低下が大きい区域となっている ことがわかる. また, 図-2に示したササの侵入がとくに 顕著な区域ともなっている. ところで, 図-11に示すよう にサロベッ川においてま, 4月は大量の融雪水により1年 で最も水位の高い時期であり, その際の涵養量の減少は その後長期にわたる地下水位の低下をもたらすと考えら れる. とくに 1 年で最も水位の低下する6,7月の初夏に乾 燥に強い植物の生育を促せば, 湿原固有の植物がより強 い圧迫を受けることも予想される.

地下水頭が高く, 透水量係数が小さい区域では天水涵 養の変動が地下水位の増減に影響し, 連続的で多量の水 の供給源である雪が大きな役割を果たしていることが示 唆できたと考える. なお, 雪の変化については近傍では 稚内気象官署で過去40年にわたる積雪深の記録があるが,

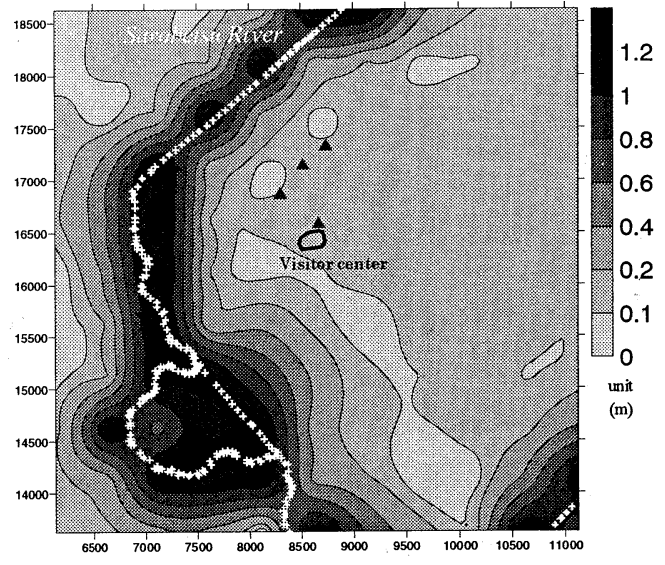

図-8＼cjkstart季節の違いによる地下水位偏差 (2000年4月と7月の差)

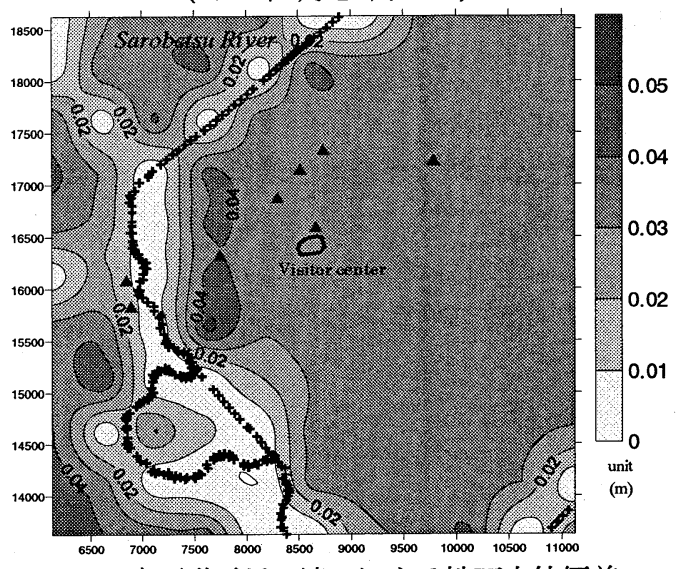

図-9 底面融雪量の違いによる地下水位偏差

(2000年2月における $2 \mathrm{~mm} / \mathrm{d}$ と $1 \mathrm{~mm} / \mathrm{d}$ の差)

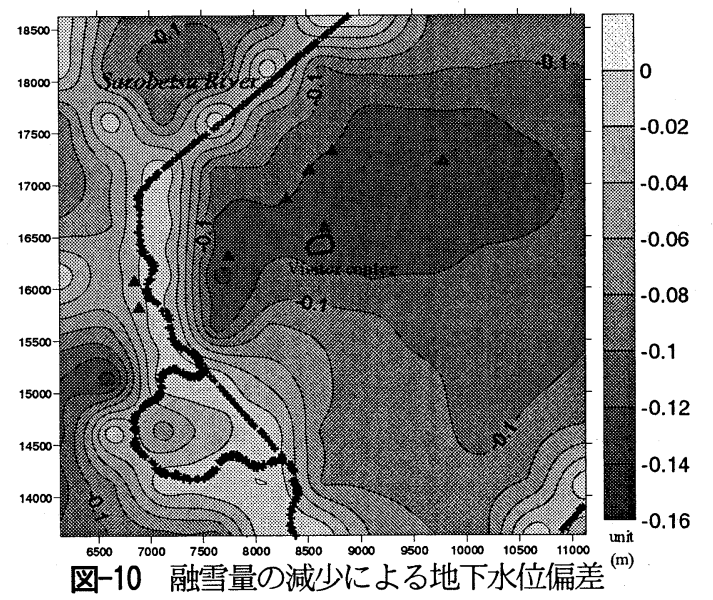

(2000年4月における現状と $100 \mathrm{~mm} / \mathrm{mon}$ 減の差)

図-12の年最大積雪深で 80 年代から90年代にかけて減少 がみられる. 流域の開発といった人為的な影響ばかりで なく, 気候変動も湿原環境に影響することが考えられる.

\section{（3）河川水位の影響}

湿原内を流れるサロベツ川の水位（開運橋地点）を年 代別, 月別に平均化したものを図-11に示す.これから 1 年でも最も高い4月の水位が近年低下傾向であることが わかる. 水位の低下でどのような範囲に影響が及ぶかは, 


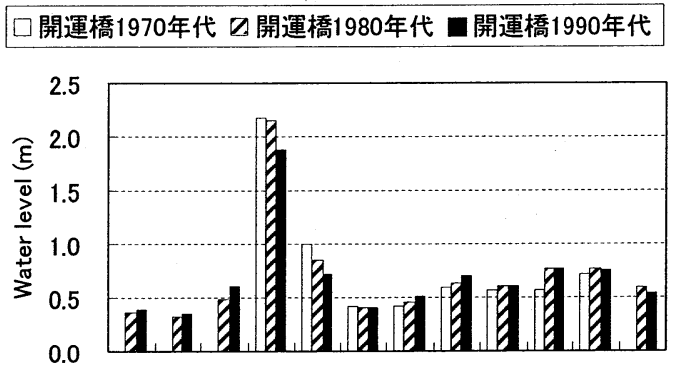

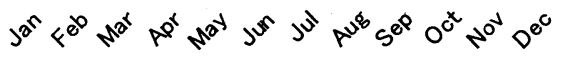

図-11 サロベツ川の年代別・季節別の月平均水位 (1971-2000のデー夕, 開運橋)

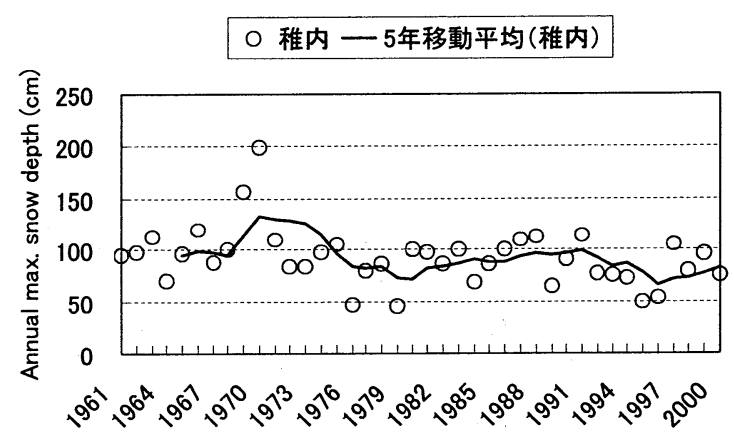

図-12 稚内気象官署における年最大積雪深の経年変化

$$
\text { (1961-2000のデータ) }
$$

2000年4月と2000年7月の計算水位差を表した図-8の結果

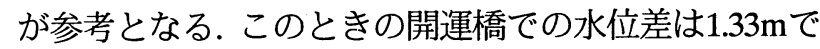
ある. 図より地下水に影響の及ふ3範囲はサロベツ川近辺 の限られた範囲であることがわかる. しかし，実際はサ ロベツ川に流入する小支川, 排水路, 湿地溝（サロベッ 川に連結した湿地内の小溝）などの水位に万遍なく影響 が及ぶとすれば，より広範囲の地下水への影響が考えら れる. これを逆手にとり, 河川や水路の水位をせき上げ て地下水位を上昇させ, 湿地の保全再生に生かすという 考え方もできる しかし, 天水涵養の条件をつくり, 高層 湿原の特徵である貧栄養的な水環境を実現できるかにつ いてはさらなる検討を必要とする.

\section{6. おわりに}

本報告において得られた結果を以下にまとめる.

1) 湿原域の地下水位は融雪期に上昇するだけでなく, 冬期積雪期に他の期間よりも高く保持されている個 所がみられる.これは積雪底面の融雪によると考え られる. 湿原域では非湿原域より底面融雪が $1 \mathrm{~mm} / \mathrm{d}$ 多いと推定された.

2) 非定常地下水シミュレーションにより, 地下水頭が 高く安定している高層湿原域の地下水変動特性を再 現した.

3) 雪が地下水に及ぼす感度を推算した結果, 底面融雪 量の増分を見込むことで高層湿原域の地下水位は数 $\mathrm{cm}$ 程度上昇することが推算され, 害際の地下水変動 と合致するような結果が得られた。
4) 融雪量の減少にともなう地下水低下域は, 天水涵養 を受け地下水位が高い個所においてより大きく影響 が現れており, 高層湿原へのササの侵入が顕著にみ られる区域と合致している

以上より, 湿原の環境変化は, 流域の開発といった人 為的影響のみならず, 降積雪の減少や融雪の早まりと いった気候要因にも注目していく必要があることを示し た. ただし，これを保全再生していくとなれば, 水位の コントロールなどでなにがしかの人為も必要と考えられ, それを評価する上でも本手法が役立つと考える.

謝辞: 本研究は平成16年度北海道開発局受託研究費の補 助を受けた. また, 地下水解析手法については山梨大学 大学院の竹内邦良教授, 石平博助教授, 中国水利部の張 祥偉氏にご指導をいただいた. さらに, 検討に用いた資 料の一部は北海道開発局留萌開発建設部および稚内開発 建設部から提供いただいた.ここに記して謝意を表する.

\section{参考文献}

1) 釧路湿原自然再生協議会HP, http://www.kushiro-wetland.jp/.

2) 冨士田裕子: サロベツ湿原の変遷と現状，（財）日本自然 保護助成基金, $1994 \cdot 1995$ 年度研究助成報告書, pp.59-71, 1997.

3) 庄子貞雄, 松実成忠, 泉谷毅一: 泥炭地の発達様式につい て(第3報), 日本土袞肥科学雑誌, 第37巻, 第8号, pp.415-421, 1966.

4) 羽山早織, 中津川誠: 湿原植生の変化をもたらす水文要因 の解析, 水工学論文集, 第48巻, pp.391-396, 2004.

5) 梅田安治, 辻井達一, 井上京, 清水雅男, 紺野康夫: サロベ ツ泥炭地の地下水位とササ -泥炭地の形態的研究(III)-; 北 海道大学農学部邦文紀要, 第16巻, 第1号, pp.70-81, 1988.

6) 張祥偉, 山本直樹, 竹内邦良, 石平博, 中津川誠, 羽山早織, 情報不足条件下での広域地下水の非定常流動解析手法に関 する研究 -サロベツ湿原を例として-, 水文・水資源学会誌 Vol.16, No.4, pp.349-367, 2003.

7) 羽山早織, 中津川誠: サロベツ湿原の地下水環境と植生変 化について, 北海道開発土木研究所月報, No.612, pp.3-20, 2004.

8) W.キンツェルバッハ著, 上田年比古監訳: パソコンによる 地下水解析, 森北出版, pp.78-119, 1990.

9) 中津川誠: 湿原の環境と水循環, 2004年度水工学に関する 夏期研修会講義集, Aコース, pp. A-2-1-A-2-24, 2004.

10) Pinder, G. F. and Gray, W. G.: Finite element simulation in surface and sub-surface hydrology, Academic Press, New York, pp. 295, 1977.

11) P. S. フヤコーン, G. F. ピンダー, 赤井浩一監訳: 地下水解 析の基礎と応用, 上巻, 基礎編, 現代工学社, pp.76-80, 1987.

12) 口澤寿, 中津川誠: 熱·水収支を考慮した流域スケールの積 雪と蒸発散の推定, 北海道開発土木研究所月報, No.588, pp.19-38, 2002. 